\title{
The seasons of a thoracic surgeon
}

\author{
James I. Fann, MD
}

\author{
From the Department of Cardiothoracic Surgery, Stanford University, Stanford, Calif. \\ Disclosures: Author has nothing to disclose with regard to commercial support. \\ Read at the 43rd Annual Meeting of the Western Thoracic Surgical Association, Colorado Springs, Colorado, \\ June 21-24, 2017. \\ Received for publication June 30, 2017; accepted for publication July 14, 2017; available ahead of print Aug 16, \\ 2017. \\ Address for reprints: James I. Fann, MD, Department of Cardiothoracic Surgery, Stanford University, 300 Pasteur \\ Drive, Stanford, CA 94305 (E-mail: jfann@stanford.edu). \\ J Thorac Cardiovasc Surg 2017;154:1477-86 \\ 0022-5223/\$0.00 \\ Published by Elsevier Inc. on behalf of The American Association for Thoracic Surgery \\ http://dx.doi.org/10.1016/j.jtcvs.2017.07.013
}

\begin{abstract}
"Life has its fixed course, and nature one unvarying way; to each is allotted its appropriate quality, so that the fickleness of boyhood, the impetuosity of youth, the sobriety of middle life, and the ripeness of age all have something of nature's yield which must be garnered in its own season."
\end{abstract}

$$
\text { -Cicero, } 44 \mathrm{BC}^{1}
$$

What is your life story? Today, I will not discuss leadership qualities or challenges in surgical education. What I will talk about is your personal and professional development - the life stages or puzzle pieces that make up your life story. First, let's celebrate your accomplishments as artists, athletes, leaders, and family members. You aspire to have a sense of purpose and meaning, and as a thoracic surgeon, you are at a place that not many years ago seemed unreachable. On this occasion, I hold up a mirror to reflect who you are and who you will be. Big data reveal your health and cardiac age and what you are likely to do when you retire. What we don't have is an understanding of the many things you have to deal with in the seasons of the thoracic surgeon's life.

Since early recorded history, the patterns of life sit at the top of the list of what people think about. You wonder, how relevant is the idea of life stages? On the basis of social psychology and observations of fellow thoracic surgeons, I propose one view of the seasons of a thoracic surgeon (Figure 1). About 30 years ago, I received a copy of Daniel Levinson's The Seasons of a Man's Life. ${ }^{2}$ What was mind-bending was the neatly laid out patterns of human development; but at that time, I scanned the middle and later stages in the book more out of curiosity than with a feeling of their relevance. Those stages are now closer to home. To avoid falling into the trap of being a motivational speaker, I base my thoughts on Levinson's work, which includes his later book, in collaboration with his wife, entitled The Seasons of a Woman's Life. ${ }^{3}$ Also relevant are Gilbert Brim's ${ }^{4}$ analysis of human nature in Ambition, George Vaillant's $s^{5}$ 75-year longitudinal study of Harvard undergraduates in Triumphs of Experience, and the ideas

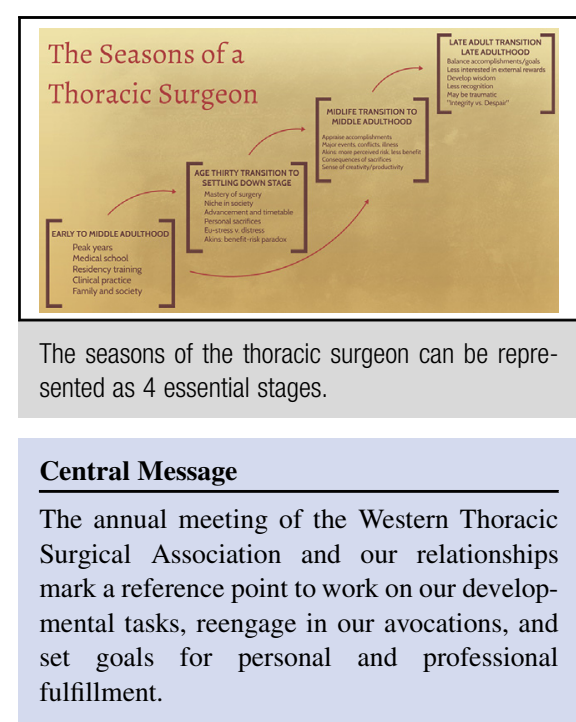

of Carl Jung, ${ }^{6}$ Erik Erikson, ${ }^{7}$ Abraham Maslow, ${ }^{8}$ and other prominent psychologists. Just as powerful are the insights from many of you in the audience.

More than 2000 years ago, Cicero $^{1}$ in writing to his close friend Atticus about the process of aging said, “... the fickleness of boyhood, the impetuosity of youth, the sobriety of middle life, and the ripeness of age all have something...which must be garnered in its own season." In the early 1900s, to Sigmund Freud, adulthood was a reenactment of unconscious childhood conflicts. ${ }^{6}$ Carl Jung, ${ }^{6}$ Freud's disciple, focused on adult development or the "second half" of life. Considered unorthodox at the time, Jung postulated that one's personality develops as a result of internal processes and external forces. ${ }^{2,6}$ The concerns of the first half of life are biologic and social, and those of the second are cultural and spiritual. ${ }^{6}$ Because one's personality is malleable, the next opportunity for change, according to Jung, starts at about age 40 years. Serving as a link between Freud and Jung, Erikson's ${ }^{7}$ view of child and adult development integrates the social sciences in defining the 8 ego stages-like an ascending staircase of things you need to do, each with its own "crisis" (Figure 2)., 5,9

To be fair to the critics of the idea of life stages, no doubt there are many variations, and everyone's path has a different terrain. So, think of these "stages" as metaphorical. Levinson ${ }^{2,3}$ analyzed life histories of people with different jobs and educational backgrounds. Evaluating the seasons of a thoracic surgeon's life seems a little easier in some respects. To the outside world, we appear homogeneous as a group because our identity is 


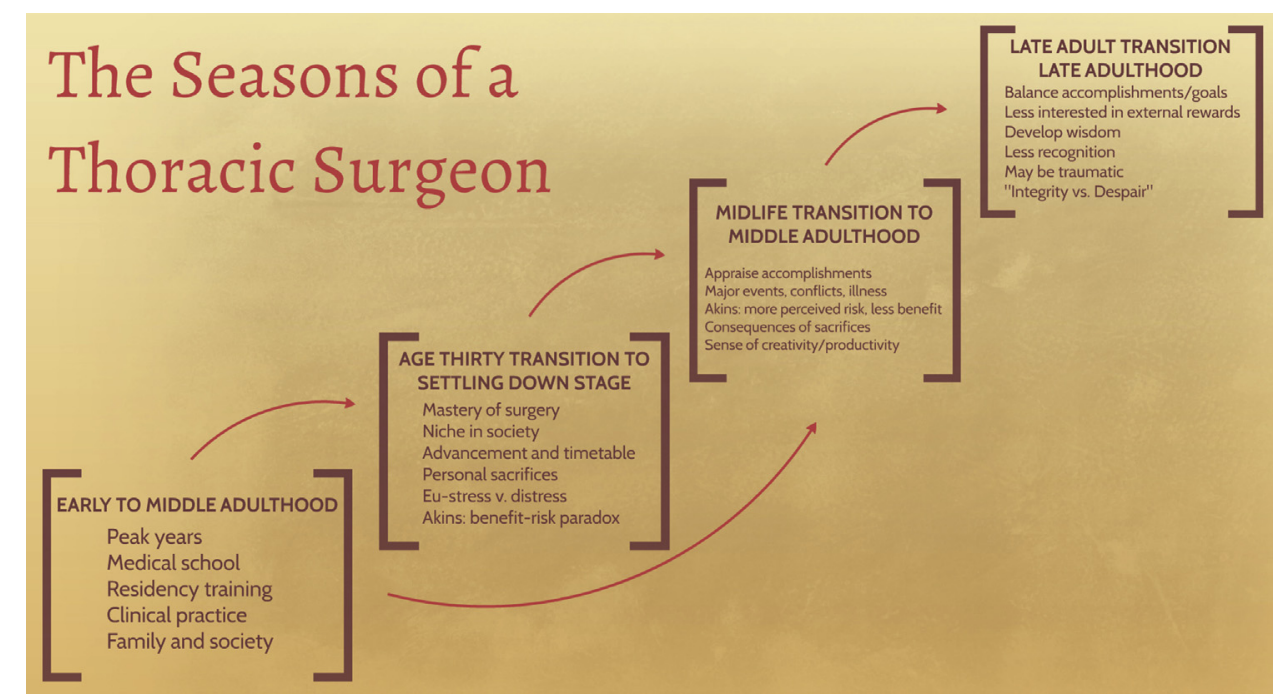

FIGURE 1. The seasons of the thoracic surgeon can be represented as 4 essential stages, which are based on the seasons of a man's life as described by Levinson. $^{2}$

tightly coupled to our vocation. At any given time, what is termed "the life structure" is composed of our social and physical environments, including family, medical practice, friendships, and peer relationships. In his presidential address 6 years ago here at the Broadmoor, Robbin Cohen ${ }^{10}$ underscored the core values of the Western, which are (1) scientific endeavor in a collegial environment, (2) education and progress, (3) development of young surgeons, (4) professionalism, and (5) family and friendship. Not a coincidence, the Western's core values parallel the

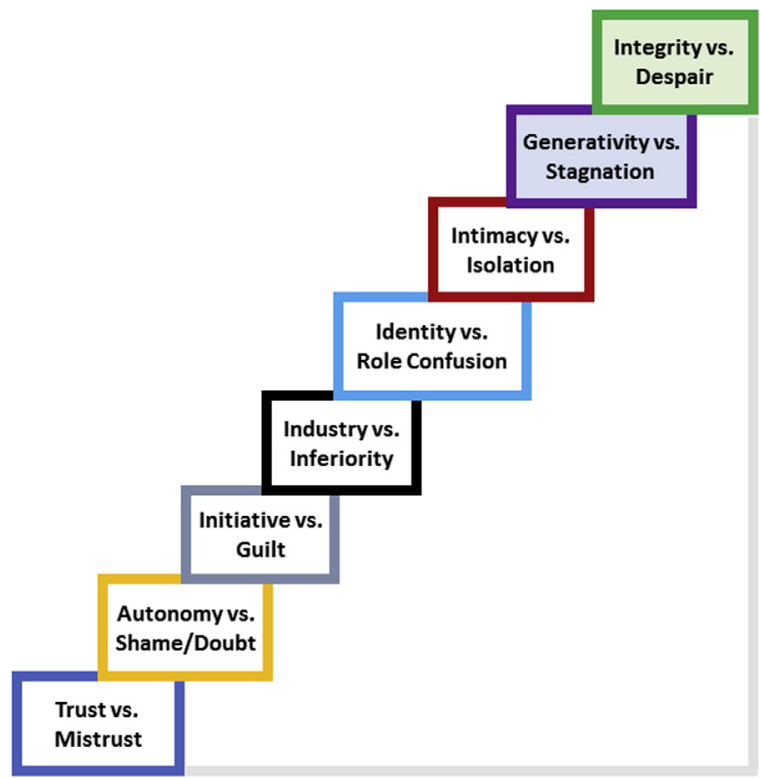

FIGURE 2. Erikson's ${ }^{7}$ view of child and adult development is represented by the 8 ego stages, each with its own crisis. Particularly relevant are "Generativity versus Stagnation" in the middle-aged adult and "Integrity versus Despair" in the older adult. life structure components that Levinson ${ }^{2}$ outlined, including the importance of introspection - that is, figuring out why as well as where you want to go on your journey.

Levinson $^{2}$ developed his stages of adulthood as follows: early adult transition starting at age 17 years (ages 17-22 years), entering the adult world at 22 years (ages 22-33 years), age 30 years transition (ages 33-38 years), settling down at 38 years (ages 38-45 years), mid-life transition at 45 years (ages 45-50 years), entering middle adulthood at 50 years (ages 50-55 years), late adult transition, and finally, late adulthood. Remember, these stages are more like unmarked fence posts than road signs and should be considered very broadly, because they do vary. But, as a metaphor and not pertaining to everyone, this template can help organize the way we think about our life story. For our consideration, I have modified Levinson's stages by accounting for the length of training and the age that most of us start our careers.

As an overview, and taking your perspective, let's look at the combined periods of early adulthood and middle adulthood (Figure 3). Beginning in your late teens and ending in your mid-50s to early 60 s are the peak years in terms of productivity and stress. ${ }^{2}$ During medical school, family and significant others support you financially and emotionally in your studies, highlighted by gross anatomy and surgical clerkships. Standing in the operating room as a first-year medical student, you are entranced and inspired by the beating heart, the inflated lungs, and the surgical dexterity. Training in general surgery defines your path with detours full of hope. Quirks and idiosyncrasies of senior residents and attending surgeons are burned into your hard-drive as they leave blotches in the hospital landscape. Recall that one meeting when the bigger-thanlife chief surgeon gives you the nod to train in thoracic 


\section{Peak years \\ Medical school \\ Residency training \\ Clinical practice \\ Family and society}

EARLY TO MIDDLE ADULTHOOD

\section{AGE THIRTY TRANSITION TO SETTLING DOWN STAGE \\ Mastery of surgery \\ Niche in society \\ Advancement and timetable \\ Personal sacrifices \\ Eu-stress v. distress \\ Akins: benefit-risk paradox}

FIGURE 3. Early to middle adulthood. This overview combines the periods of early adulthood and middle adulthood. Beginning in your late teens and ending in your mid-50s to early 60 s are the peak years in terms of productivity and stress.

surgery with a firm handshake. Life as a resident is defined simply in temporal blocks, measuring the passage of time by the number of months remaining on the various rotations. ${ }^{11}$ Pushed to the limit, you perform life-sustaining procedures during all hours. As a chief resident once quipped, "There's nothing like going on pump." You arrive breathless to a code in the intensive care unit or walk the halls of the hospital at night when the only person that crosses your path is the X-ray tech on his way to the emergency department. Your community is your fellow trainees. To many of you, but not to your family-as time marches on for them-residency seems like "one long day." As you progress and perhaps start a family, the first years are hectic with young children swaying the balance.

Specifically, in this early adulthood period, including the age 30 years transition extending into the settling down stage in your early 30 s to mid-40s (Figure 4 ), ${ }^{2}$ a new city beckons as you begin to tackle the pushes and pulls of patient care and the health care landscape. Much to your spouse's relief, you start to reap the rewards of all the training. Crucial to your development but largely neglected are past friendships, community, and time for yourself. You ambitiously set long-term professional goals and a distinct timetable for attaining them. The major tasks are to become expert in surgery and to establish a niche in society. You start to realize what The American Association for Thoracic Surgery (AATS) past president Bruce Lytle ${ }^{12}$ means when he says, "The core values of cardiac surgery have been seriousness, personal responsibility, technical excellence, intellectual credibility, leadership, and mentoring." Conscious and unconscious sacrifices weave their way through life's intricate fabric. Work and family time often conflict, and you avoid asking why these conflicts often resolve in favor of work. Because you are challenged with growth and productivity in your new practice, the stress at work is mainly eustress (or good stress). Unlike distress, with its adverse mental and physical effects, eustress is
FIGURE 4. Age 30 years transition to settling down stage. In this early adulthood period, including the age 30 years transition extending into the settling down stage in your early 30 s to mid-40s, you tackle the challenges of patient care and the health care landscape, but largely neglected are past friendships and time for yourself.

exhilarating and motivating. In a CTSNet opinion piece, Cary Akins ${ }^{13}$ reflects on the paradox of the decreasing benefit relative to risk for you-the surgeon-over your long career. The early period, as Akins recalls, is a highly rewarding time when most cases are associated with valuable learning and gratitude from the patients and their families. Because you do not fully appreciate the potential consequences of what appears to be minor technical mistakes, you have more perceived benefit and less perceived risk. ${ }^{13}$

As a young surgeon, you promote yourself and grapple with the ever-changing regulations and the dynamic patient acuity and volume. Entering the mid-life transition in your 40 s leading to middle adulthood in your 50 s and early $60 \mathrm{~s}$, the life structure questions no longer revolve around your potential, but instead you appraise what you have accomplished and how you relate to your family and community (Figure 5 ). ${ }^{2}$ Major events have become matters of course, such as promotions or conflicts at the hospital, rewards and difficulties of family life, personal illness, and the illness of those close to you. ${ }^{2}$ A shift in your aspirations stretches and contorts your precious timetable. After 25 years in practice, in middle adulthood, Akins ${ }^{13}$ in his CTSNet article now opines that with each current procedure, you perceive more risk and less benefit when compared with your early practice. "Bad things" or complications happen. So, what is the prime motivation at this point? It's all about the patients, their gratitude and that of their families. Akins ${ }^{13}$ finds that building a team of professionals who produce excellent clinical results leads to an increased sense of fulfillment. In middle adulthood, you come to grips with the consequences of earlier sacrifices. The Society of Thoracic Surgeons past president Mike Mack ${ }^{11}$ observes, "Our families cannot understand why we go on a family vacation and we are grumpy or preoccupied or distant. It's not that we don't want to enjoy 


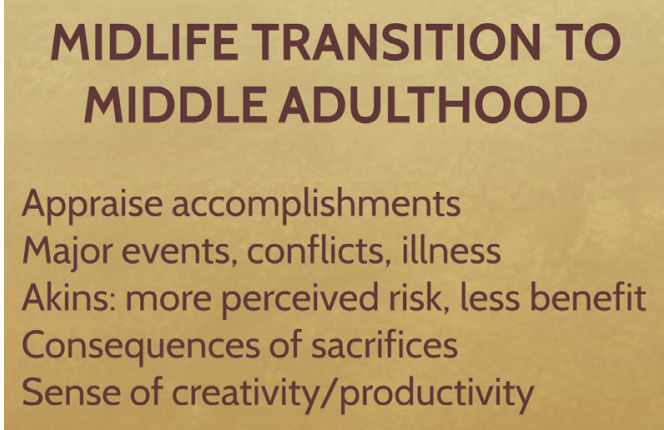

FIGURE 5. Midlife transition to middle adulthood. Entering the midlife transition in your 40 s leading to middle adulthood in your 50s and early $60 \mathrm{~s}$, you appraise what you have accomplished and how you relate to your family and community.

our vacation; it's just that we are still worried about that patient that we left behind in the intensive care unit." Yet, through it all, Lady Fortune has blessed you because there is no other profession that can provide such a sense of pride and purpose. The AATS past president Craig Smith ${ }^{14}$ acknowledges, "Family life is the most important thing we sacrifice at the altar of healing.... without the love for and from my wife and my family, none of it would be worthwhile." Also at this stage, you feel more creative and productive as you see the bigger picture, and according to Levinson, you "suffer less from the tyranny of youthful ambitions, passions and illusions.",

Crossing the bridge from the first half to the second half of life leads to what the introspective Jung ${ }^{6}$ terms "individuation," which is a period of soul-searching and generating personal awareness, meaning and understanding. ${ }^{2,5}$ Until your late 30s, life by necessity is off kilter. According to Jung, early adulthood is the time when you are highly motivated to look after "number one," focusing all the energy into your training, practice and family; your development is 1-sided devoting little time to yourself and to your inner life. ${ }^{6}$ In the second half of life or middle adulthood, the developmental task is pursuing the path of individuation or knowing yourself, aspiring to achieve your fullest development by reflecting upon and integrating all that has been learned-namely, your identity, your consciousness, and the unconscious (both personal and collective). ${ }^{6}$ As the psychologist James Hollis ${ }^{15}$ says in The Middle Passage, "Our task at midlife is to be strong enough to relinquish the ego-urgencies of the first half and open ourselves to greater wonder."

In this second half of life, Erikson's ${ }^{7}$ ego stage of "Generativity versus Stagnation" knocks at the door (Figure 2). Generativity in part relates to developing the next generation, so the task is to assume responsibility for the new generation of young surgeons. The alternative is to become disengaged and stagnate. In reviewing the core values of the Western, it is imperative to develop young surgeons through mentorship and nurture the clinical team. ${ }^{10}$ Cicero reflects, "What nobler employment, or more valuable to the state, than that of the man who instructs the rising generation?" 16 Find time to mentor residents or junior partners or participate in student shadowing programs, which are activities vital to your personal "state" and the state of surgery. As the Southern Thoracic past president Rob Cerfolio ${ }^{17}$ stresses, "Super performers, great athletes, and surgeons require continued realignment from mentors; from beacons in the night." The goal is to become a beacon of light to others by understanding why and how your mentors became your beacons.

Although history tells us that most discoveries are made when one is young in early adulthood, you in middle adulthood can clarify the bigger picture. With the expansion of knowledge, many discoveries indeed are being made later in life. The touchstone at national meetings is often innovation. In the current era of increasing regulations and health care costs, you in middle adulthood are tasked with developing innovative and creative models for providing care. In his book Old Masters and Young Geniuses: The Two Life Cycles of Artistic Creativity, the economist David Galenson ${ }^{18}$ describes 2 different types of artists and scholars, distinguished by how they arrive at their creations. ${ }^{19}$ One is conceptual or the desire to communicate specific ideas through sudden innovations, a process that usually occurs earlier in life; the second one is experimentation that develops incrementally, which usually appears in later works. ${ }^{18}$ For instance, the artist Picasso says, "I don't seek; I find," 18 reflecting his early genius through a series of sudden discoveries, which are independent of his previous works. Paul Cezanne, on the other hand, says, "I seek in painting," 18 which is experimental innovation that is incremental. Because there is no direct way to measure the quality of an artist's work over the course of his career, Galenson ${ }^{18}$ uses auction prices as an indirect measure. At auction, Picasso's painting reached a peak with Les Demoiselles d'Avignon painted at age 26 years; a painting he did that year is worth more than 4 times as much as one the same size he painted when he was 67 years old. ${ }^{18}$ On the other hand, Cezanne's later works are valued most highly, with a painting he did at age 67 years worth 15 times compared with a same-sized painting he painted at age 26 years. Also, the great works of the poets Robert Frost and William Carlos Williams, the filmmakers Alfred Hitchcock and John Ford, and the writers Mark Twain and Charles Dickens are all products of their middle adulthood and even later. ${ }^{18}$ The great lesson here is that with deep understanding of thoracic surgery, you are primed to create and innovate in your middle adulthood, more in an incremental sort of way, just like Cezanne, Frost, and Dickens. Cicero says that important "affairs are not performed by muscle, speed, (and) 


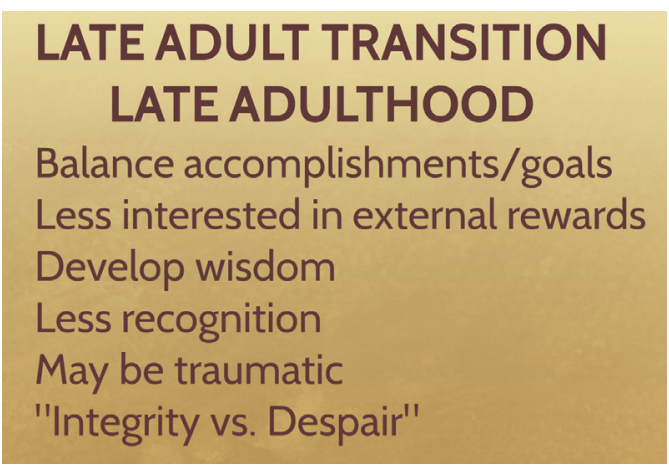

FIGURE 6. Late adult transition to late adulthood. At this stage, the task is to find a balance between your surgical accomplishments (clinical productivity or academic pursuits) and your goals going forward.

nimbleness, but by reflection, character, (and) judgment... (as one ages) these qualities are not diminished but augmented."1

The next life stage is late adult transition, which greets you in your 60s on the way to late adulthood (Figure 6). ${ }^{2}$ The AATS past president Floyd Loop ${ }^{20}$ reflects, "I believe that my life has been like a clear day in the high Sierra, and with all the sharp ridges and steep gorges, it has been an exhilarating experience being part of this profession. The season now is autumn, but I still see sunbeams every day, for which I am deeply grateful." At this turning point, an important developmental task is to find a balance between your surgical accomplishments-that is, your clinical productivity or your academic pursuits - and your goals going forward. You become less interested in obtaining external rewards and more keen on gaining wisdom. According to Socrates and Aristotle, wisdom lies in a balanced attitude toward what you think you know, knowing what you do not know, and at the same time, not being paralyzed by doubt. ${ }^{21,22}$ Important to wisdom is transcending one's biases, which can distort one's perception, and to have a high tolerance for uncertainty, because it is not easy to make reliable judgments. ${ }^{22,23}$ As the psychologist Jonathan Haidt ${ }^{24}$ says in the book The Happiness Hypothesis, "A good place to look for wisdom...is where you least expect to find it: in the minds of your opponents."

In late adulthood, Levinson ${ }^{2}$ stresses that you can no longer occupy the center stage and should reduce your professional responsibilities, which can be quite traumatic as you receive less acclaim and recognition. After all, the next generation of surgeons needs room to advance. The AATS past president Alec Patterson ${ }^{25}$ warns, "We need to be mindful about self-promotion at a senior stage of our career. Young people will not receive good mentorship from senior colleagues for whom self-promotion is important." During this period, Erikson's ${ }^{7}$ final ego stage of "Integrity versus Despair" emerges (Figure 2). This developmental task is to gain a sense of integrity in your life-not simply integrity of your virtue, but of your life as a whole. Take pride in your accomplishments as you reflect and review your career with a sense of wisdom and contentment. Success in this task shields you from bitterness and despair. In transitioning to this stage, Jimmy Edgerton $^{26}$ says, "To be a great heart surgeon, heart surgery has to be who you are, not what you do. When you retire, heart surgery is what you do, not who you are." As a further reality check, the Society of Thoracic Surgeons past president Ben Wilcox ${ }^{27}$ reflects, “...for many years I maintained the rather naive belief that as I got older, life would become simpler-that with advancing age and increasing wisdom I would...sort out life's problems and the complexities of living would wither by the wayside. Of course, nothing could be farther from the truth." So, what does the psychiatrist George Vaillant ${ }^{5}$ say after culling through 75 years of longitudinal follow-up of Harvard male sophomore students (from the study that was initiated in 1938)? He found that childhood trauma becomes less important with time, while the good things that happen in childhood endure. Also, personal development, along with its many challenges, is really a lifelong process that extends well into late adulthood. Even if one has a midlife that has little hope, one can blossom and find joy in old age.

By now, you're probably wondering, what happens when we neglect our personal needs and developmental tasks? Recall the core values of the Western that emphasize the collegial environment and family and friendship. In studies of positive psychology, Haidt ${ }^{24}$ says that the strength and number of a person's relationships usually overshadow all others in importance. Simply, good relationships make people happy, and in a cyclical fashion, happy people enjoy better relationships. $^{24}$ Seven years ago, Scott Millikan ${ }^{28}$ in his presidential address insightfully spoke about the importance and fragility of relationships in his life, family, and community; for us, "Friends and family are clearly at the heart of this organization." The psychologist Gilbert Brim ${ }^{4}$ points out that of all the occupations, garbage collectors rank the lowest in occupational prestige and in their self-esteem as it relates to their work, but they are the second highest in their pride in their families. This finding is simply because workers in lower-status occupations focus on their families as their area of achievement. On the other hand, college professors, who are near the top of occupational status, are low in their pride and self-esteem about their families. ${ }^{4}$ We must decide how to balance our successes and failures, realizing as Brim says, "the painful price of the process of blissful absorption in one domain for neglect/loneliness/poor performance in another domain" has to be paid. ${ }^{4}$

In planning for the future and believing in second chances, many stop trying after the second or third try, or maybe after 
the fourth try, even though they may eventually succeed if they continue. ${ }^{4}$ For instance, 5 of the best-selling works of the 20th century, including Dr Seuss's And to Think That I Saw It on Mulberry Street, Richard Hooker's $M * A * S * H$, Thor Heyerdahl's Kon-Tiki, Richard Bach's Jonathan Livingston Seagull, and Patrick Dennis's Auntie Mame, were each rejected by 17 or more publishers. ${ }^{4}$ For the younger members in the audience, Harry Potter and the Sorcerer's Stone was rejected by 12 publishers. ${ }^{29}$ You know in surgery that persistence is not to be underestimated even when the odds of success seem slim. Many times, it is that third or fourth try that results in success in the operating room. But, you also know the converse is true; that is, we think we will have another chance and only later realize that we do not. ${ }^{4}$ This idea is particularly true with relationships. Let's say one late evening, you walk by a store and see the perfect tie or scarf for your spouse in the window; you return the next day, and you find that the it has been sold and is no longer available anywhere. Instead of the example of the gift for your spouse, let's say it's your child's guitar recital or basketball game or volleyball tournament. It is these errors in judgment that lie behind "the saying that in the end we are more sorry for what we did not do than what we did do." ${ }^{4}$ In our capacity to change, spend time with those we care about because we may not have another chance.

Here is my proposal: Not confronting the developmental tasks in our life stages and not reflecting on our progress can manifest in a weariness that is becoming more and more common-namely, what is frequently and generically referred to as burnout, both personal and professional. The psychologist Christina Maslach ${ }^{30}$ in Burnout: The Cost of Caring describes burnout in medicine specifically as a syndrome of emotional exhaustion, depersonalization (or callous response when caring for a patient), and lower sense of personal accomplishment. It stems from the stress experienced by those who provide extensive care to others and the associated chronic emotional strain-basically it is what we see and do every day as thoracic surgeons. As Mike Mack ${ }^{11}$ reminds us, "Each time... a patient dies or has a major complication, even if we did everything the best possible way it could be done, a little bit of our soul, a little bit of us dies with them." What contributes to professional burnout? When the workplace does not recognize the human side of work and there are mismatches between the nature of the job and the nature of people, then burnout will creep up and rear its ugly head. ${ }^{30}$ These real and perceived mismatches can be reflected in 6 ways: work overload, lack of control, insufficient rewards, breakdown of workplace community, absence of fairness, and conflicts relating to values, such as that between you and your co-workers or between you and the institution (Figure 7) ${ }^{30}$ In the current health care environment, we don't need to stretch our

\section{Mismatches}

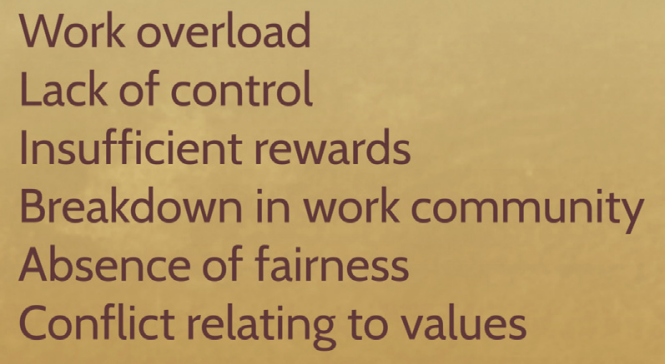

FIGURE 7. Mismatches between the nature of the job and the nature of people that lead to burnout as defined by Maslach. ${ }^{30}$

imagination to appreciate how these mismatches abound. In the short term, one is able to adjust. But how about in the long run?

The Mayo Clinic group reports that more than half of physicians (ie, 54\%) showed at least 1 symptom of burnout, an $8 \%$ absolute increase (from $46 \%$ ) between 2011 and $2014 .{ }^{31}$ In general surgical subspecialties, the prevalence of burnout is not much different at $53 \%$, increased from $42 \%$ just 3 years prior. $^{31}$ Thoracic surgery is not far behind. ${ }^{32}$ No doubt many external factors are at play, such as workload and administrative burdens, including the electronic health record. Along with mismatches at work, there are many personal risk factors for burnout. For instance, a recent work-home conflict puts one at risk, especially when the conflict is resolved in favor of work. ${ }^{33}$ Also, younger surgeons tend to be at higher risk, partly because they have not adjusted to the stresses and expectations regarding the balance of career, family, and personal development. ${ }^{33,34}$

Up to now, there is no single, effective strategy to improve one's well-being and mitigate burnout. What has been proposed by others include identifying personal and professional values, enhancing areas of work (and life outside of work) that are most meaningful, and nurturing wellness strategies. ${ }^{35}$ To many, these recommendations tend to be a little too transparent or abstract. Remember that vital in your career is your ability to adjust to challenges in and out of the operating room; that is, your strength is your cognitive flexibility and adaptability. Grit and lifelong learning are in your DNA. The Mayo Clinic is gathering data regarding organizational characteristics that help physicians thrive. ${ }^{36}$ In the meantime, to improve one's sense of wellness, one must reflect on the personal and professional priorities, that is, really dig deep and identify where they are in conflict and manage these conflicts. ${ }^{35}$ In other words, we need to confront the tasks and resolve the crises in the stages of our development. It's not a question of being more or less insightful or disciplined, it's being human. 


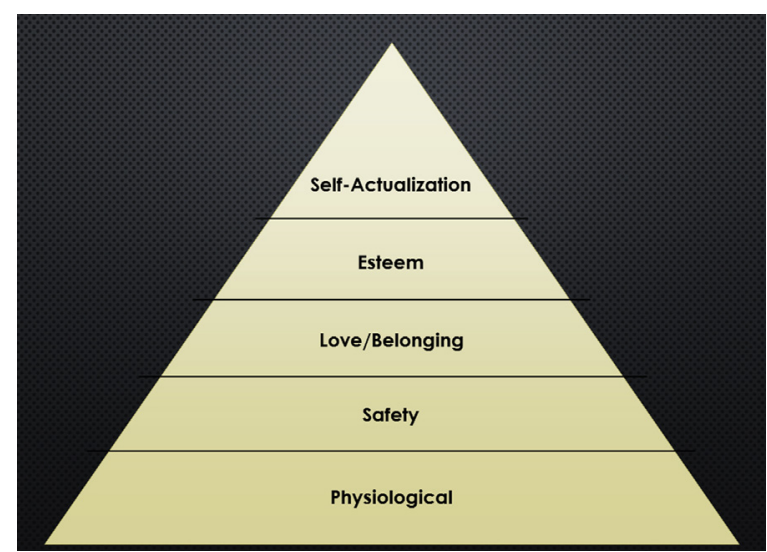

FIGURE 8. Maslow's ${ }^{8}$ pyramid or hierarchy of needs. The first 4 components are termed "deficiency" needs. Self-actualization includes fully and selflessly experiencing life, making "growth" choices, and recognizing brief moments of joy or "peak experiences."

You know you are motivated. But how are you motivated and why do you do what you do? About 70 years ago, Abraham Maslow ${ }^{8}$ developed the idea of a hierarchy of needs or Maslow's pyramid-simply why we do what we do (Figure 8). The first 4 components are termed "deficiency" needs, that is, they must be fulfilled before moving on to the higher levels. Going up the pyramid, you have fulfilled basic physiologic needs and, for the most part, those relating to safety and security; you continue to work on or have tackled belonging and love and the fourth one-that of a sense of self-esteem. Look around, in your daily life at home and in the hospital and here at this meeting, you can see how these needs are manifested-especially with respect to belonging and sense of self-esteem. Maslow ${ }^{8}$ viewed the upper part of the pyramid to include the various aspects of selfactualization and personal growth. Self-actualization includes fully and selflessly experiencing life, making "growth" choices, and recognizing brief moments of joy or what he termed "peak experiences." 8 In a sense, Maslow's idea of self-actualization parallels Jung's concept of individuation. So what happens when one is mired in the "deficiency" needs of trying to achieve financial security and establishing one's sense of self-esteem? Is it possible that burnout, particularly among younger surgeons, stems from rough patches in dealing with these deficiency needs and not being able to acknowledge the need for growth? In making a case for an attitudinal change among thoracic surgeons and pertaining to finances, Doug Wood ${ }^{37}$ in his presidential address recounts the advice he received from his mentor Doug Mathisen: "Decide how much money that you need, how much you feel that you are worth, how much you need to support your family. Once you meet that threshold, don't let the allure of more money dissuade you from doing what you want to do or being where you want to be." To put it into the context of Maslow's paradigm, once you determine your financial threshold (or financial safety and security) and are able to fulfill it, recognize the importance of moving up the hierarchy of needs to self-actualize and achieve personal and professional fulfillment. Viewed in a slightly different way, as Rabbi Schachtel ${ }^{38}$ says, "Happiness is not having what you want. It is wanting what you have."

This idea is so wise and pure and yet so very difficult to apply... which brings up the theory of relative deprivation and the story of the American Soldier study conducted by the sociologist Samuel Stouffer during World War II. ${ }^{39}$ In assessing morale in the military, Stouffer found that black soldiers stationed in the US South were more satisfied and had higher morale than those stationed in northern states despite the outward racism and segregation in the South in the 1940s. So what do you make of this unexpected finding? Stouffer proposed that people are unconsciously comparing themselves with others around them, particularly those they consider to be like themselves, and then making evaluations, often with extreme emotions, about their own experience using that reference. In the study, black soldiers in the South thought their situation to be favorable compared with that of black civilians in the South; they did not compare themselves with black soldiers in the North with whom they had no contact. ${ }^{39}$ On the other hand, black soldiers in the North had a lower morale because they viewed their station comparatively worse than that of black civilians in the North. So, a person's sense of work satisfaction and accomplishments is relative to the available comparisons that he or she has. To illustrate, just reflect on how you feel when that surgeon down the street gets more referrals and does more cases than you. Also, have you heard of what many have referred to as "Facebook Envy" in social media? Relative deprivation emphasizes that it is not always our objective situation that determines our level of happiness, but our perception of deprivation relative to that person or group that we are using as a comparison. To relate this idea to those of Maslow, ${ }^{8}$ do these comparisons lead to an increased sense of security or belonging? Probably not. More likely, it is the sense of self-esteem bubbling over. In effect, although we may not be able to stop comparing ourselves with others, to decrease stress and perhaps decrease the likelihood of burnout, we need to carefully choose our reference and determine the value, or the lack thereof, that we should place on such perceptions or misperceptions in our careers and in our lives.

As an aside, you know that whenever something bad happens, the distress you feel decreases over time. ${ }^{40}$ You also know that if something really good happens, such as a promotion or membership to an organization such as the Western, the thrill associated with it also abates with time, sometimes as quickly as within days or months. Sheldon and Lyubomirsky ${ }^{40}$ term this phenomenon "hedonic 
adaptation," which says that everyone adapts and gets used to good news or happy events. It really challenges the thinking that a person can become and remain happier simply by changing his or her job or buying a new sports car. An extension of this idea is that one will keep adapting or getting used to things as one continues to have more positive events associated with the original event. ${ }^{40}$ That is, let's say you have a successful surgical practice that leads to more stuff and a higher standard of living; this standard then becomes your new norm, so that you will want more as your standard continues to rise. As an example, after Thriller became the best-selling record album of all time, Michael Jackson reportedly remarked that he would not be satisfied unless his next album sold twice as many. ${ }^{40}$ So, is there a way to stay happier longer or slow down the process of getting used to all the rewarding things that have happened to us and the relationships that we have? It appears that adaptation occurs only in response to constant or repeated stimuli and not to unexpected or surprising stimuli, which are innately more interesting. ${ }^{40}$ By accentuating and appreciating the variability and novelty inherent in our experiences, we are less likely to become used to it. That is, true appreciation of that wonderful event-to savor it, to feel grateful for it, to recognize that we might lose it - can lessen the adaptation process. Think about the positive changes in our lives, including our families, current practice, and social groups. Appreciation for who we are and what we have keeps us from taking the good stuff for granted-importantly, it allows us to extract the most from the present. In essence, to echo an earlier thought, find ways to want what we have.

Recognizing the need to reflect and understand the basic components that drive us, how can we move forward - that is, to individuate, to self-actualize, and to avoid or mitigate burnout? Perhaps the most powerful approach is to alter our mindset, as the psychologist Carol Dweck ${ }^{41}$ proposes, from a fixed mindset to a growth mindset (or I would argue from a fixed attitude to a reflective and introspective attitude). Growing our mindset can lead to the love of challenges and resilience in the face of obstacles. By the way, it is Mueller and Dweck ${ }^{42}$ who studied motivation among fifth-grade students and found that those who are praised for their intelligence have worse outcomes than those who are praised for their effort. Those praised for their intelligence avoid challenges, and after failure, these children tend to think that intelligence is fixed and cannot improve. In contrast, students praised for their effort prefer tasks that are challenging with greater enjoyment of the tasks. $^{42}$

So, going back to Dweck's ${ }^{41}$ concept of mindsets, what does this idea have to do with us? In short, we have to change from a fixed mindset to a growth mindset to selfactualize and to address burnout. We need to recapture our sense of gratitude and wonder. But it is not easy-it can be unsettling. We may feel like we won't be ourselves anymore. After all, it's our fixed mindset that led to our ambition and our success, right? The answer is no. Dweck ${ }^{41}$ argues that opening up to a growth mindset makes us more like our true selves, not less. We need to remove the self-imposed constraints. So we say, we will change tomorrow and adopt a growth mindset. But you know what? Psychologists tell us that we will not. ${ }^{41}$ When we get home next week, we will be back in the operating room, and we will go about our business as usual. To change our mindset-or to put it another way to advance our life story-we have to visualize and write down specific, concrete plans of when, where, and how we're going to change. We have to write down how we are going to improve. Take small steps to start. To sustain the change requires that seeing things in a new way. Specifically, reassess our needs, particularly those Maslow needs of security, belonging, and esteem, and express the need to self-actualize. Generate a hierarchy of needs of our own: Determine what we have to have and what we can do without. Ask what is it that we most enjoy about what we do and how we can frame our vocation-our practice-to increase meaning and focus in those enjoyable areas. Nurture professional relationships and tap into the experience of colleagues. Talk to those sitting next to you in this room-that is, really talk about values, interests, and opportunities. There is nothing like relating to someone who has also been in the trenches, especially those with whom we share a surgical past.

Knowing that it is not possible to stop comparing our situation with that of others, acknowledge our many extraordinary accomplishments and don't let our emotions get the best of us. Appreciate and find intrinsic enjoyment in our experiences and professional and personal relationships so we do not take them for granted. Define specific hobbies and take on a cause, assisted by family and friends. As the Southern Thoracic past president Joe Miller $^{43}$ urges, "the complete cardiothoracic surgeon should have a hobby outside of medicine"; otherwise, he will become "stale" and withdrawn. Also critical is to undertake projects that tap our creativity and inspiration, such as playing music, woodworking, or painting, because Maslow ${ }^{8}$ proposes that the concept of "creativeness" or creativity and the need for self-actualization may, in fact, "turn out to be the same thing." Recall that innovation is often experimentation that develops incrementally as demonstrated by Cezanne. As Jung pointed out more than half a century ago, focus on that part of us that we have neglected in the stages of our development. ${ }^{6}$ Reflect and strive for coherence by improving our physical health, psychologic and emotional well-being, and social development by maintaining friendships and a sense of community. ${ }^{24}$ And because many of you are in leadership positions, be especially tuned in to your 
colleagues, and take time to mentor those who are your junior and those who are becoming emotionally exhausted. After all is said and done, the AATS past president Irv Kron ${ }^{44}$ concludes, "Balance is everything. We must be able to look after our families, our friends, and ourselves."

Cicero's seasons of life highlight time marching in the stages of our professional and personal lives. Let's reflect on and reaffirm our accomplishments as artists, athletes, leaders, and family members. The Western and our relationships with our friends and colleagues mark a reference point for us to work on our developmental tasks, reengage in our avocations, and set new goals for personal and professional fulfillment. So, when you wonder why I look forward to this meeting, it is because of the importance of this community, the network connecting all of us, and the richness of reflection-nothing less.

As I reflect on the many who have guided me in my seasons, I ask you to think about those who made yours a little easier. For me, in medical school, Jerry Loeb, John Moran, and Jim Frederiksen were instrumental in fueling my interest in cardiothoracic surgery. At Stanford, I am forever indebted to Craig Miller, who provided the opportunity to work in his lab and who helped me define my professional path. I am also fortunate to have as teachers Mario Pompili, Scott Mitchell, Phil Oyer, Bobby Robbins, Jim Mark, Walter Cannon, Vaughn Starnes, Ed Stinson, Bruce Reitz, Harry Oberhelman, and Dr Shumway. My valued Stanford colleagues include Joe Woo and Mike Fischbein, along with the many others on our exceptional staff. My involvement with surgical education has led to lifelong collaborators, including Rick Feins, John Calhoon, Jeff Hicks, and especially those in the Western, including Nahush Mokadam, Craig Baker, Susan Moffatt-Bruce, Richard Shemin, Dave Fullerton, and Ed Verrier. I am indebted to my current and past trainees; they have been vital to my development. Here, at the Western, I have been the recipient of the wisdom of past presidents, councilors, and many of you in the audience. I especially want to acknowledge my teacher, colleague, and close friend Tom Burdon, who has been integral in my development and who remains the pillar in my professional life.

Very special are members of my family. Here supporting me today are my great kids, whose nicknames are as unique as their personalities—Kiki, Bay, and Buzz — of whom I am extremely proud. And my deepest and heartfelt love and appreciation go to my wife Andie, who radiates sunlight and deserves the credit for all the good things that have happened in my life; I am blessed with her unwavering love and timeless sense of humor.

I sincerely appreciate the wonderful opportunity that all of you have afforded me to serve this year and for allowing me to share this moment with you. I wish all of you well. Thank you.

\section{References}

1. Cicero MT. (44 BC). On old age. In: Hadas M, ed. The Basic Works of Cicero New York, NY: Random House; 1951:125-58.

2. Levinson DJ. The Seasons of a Man's Life. New York, NY: Ballantine Books, Random House, Inc; 1978.

3. Levinson DJ, Levinson JD. The Seasons of a Woman's Life. New York: Ballantine Books; 1996.

4. Brim G. Ambition: How We Manage Success and Failure Throughout Our Lives New York: Basic Books; 1992.

5. Vaillant GE. Triumphs of Experience: The Men of the Harvard Grant Study. Cambridge, MA: Belknap Press; 2012.

6. Jung SA. A Very Short Introduction. New York: Oxford University Press; 1994

7. Erikson EH, Erikson JM. The Life Cycle Completed (Extended Version). New York, NY: W.W. Norton \& Company; 1997.

8. Maslow AH. The Farther Reaches of Human Nature. New York: Penguin Books: 1976.

9. Agronin ME. From Cicero to Cohen: developmental theories of aging, from antiquity to the present. Gerontologist. 2014;54:30-9.

10. Cohen R. Our "default future" J Thorac Cardiovasc Surg. 2011;142:961-96.

11. Mack MJ. If this were my last speech, what would I say? Ann Thorac Surg. 2012; 94:1044-52.

12. Lytle BW. Who we are - who we will be. J Thorac Cardiovasc Surg. 2008;135:965-75

13. Akins C. Paradox of the deteriorating risk/benefit ratio of increasing surgical volume...for the surgeon, CTSNet In My Opinion. Available at: http://www.ctsnet org/article/paradox-deteriorating-riskbenefit-ratio-increasing-surgical-volume $\%$ E2\% $\%$ \% \% A6for-surgeon. Accessed May 3, 2016.

14. Smith CR. AATS 2012: "To model excellence." J Thorac Cardiovasc Surg. 2012;144:749-58.

15. Hollis J. The Middle Passage: From Misery to Meaning in Midlife. Toronto: Inner City Books; 1993:114-5.

16. Marcus Tullius Cicero quotation. Available at: http://www.rightwords.eu/quotes/ what-nobler-employment-or-more-valuable-to-the-state-6057. Accessed May 4, 2016.

17. Cerfolio RJ. The athleticism of surgery and life: super performing at work and at home...And beacons of light. Ann Thorac Surg. 2014;98:1529-35.

18. Galenson DW. Old Masters and Young Geniuses: The Two Life Cycles of Artistic Creativity. Princeton, NJ: Princeton University Press, Princeton and Oxford; 2006.

19. Gladwell M. Late Bloomers: Why Do We Equate Genius with Precocity? The New Yorker. October 20, 2008. Available at: http://www.newyorker.com/ magazine/2008/10/20/late-bloomers-malcolm-gladwell. Accessed May 4, 2016

20. Loop FD. The first living and the last dying. J Thorac Cardiovasc Surg. 1998 116:683-8.

21. Kitchener KS, Brenner HG. Wisdom and reflective judgment: knowing in the face of uncertainty. In: Sternberg RJ, ed. Wisdom: Its Nature, Origins, and Development. Cambridge: Cambridge University Press; 1990:212-29.

22. Moody HR. Does creativity decline with age? In: Aging: Concepts and Controversies. Thousand Oaks, CA: Pine Forge Press (Sage Publications); 2002:359-90.

23. Orwoll L, Perlmutter M. The study of wise persons: integrating a personality perspective. In: Sternberg RJ, ed. Wisdom: Its Nature, Origins, and Development Cambridge: Cambridge University Press; 1990:160-77.

24. Haidt JH. The Happiness Hypothesis: Finding Modern Truth in Ancient Wisdom New York: Basic Books; 2006.

25. Patterson GA. Non solus-a leadership challenge. J Thorac Cardiovasc Surg. 2010;140:495-502.

26. How to transition from cardiothoracic surgeon to retiree. Moderated by James Edgerton. Available at: https://www.youtube.com/watch?v=Fux1sBJMpeg. Accessed December 14, 2016.

27. Wilcox BR. "A half-dead thing..." Ann Thorac Surg. 1995;59:1047-55.

28. Millikan JS. Bigger. J Thorac Cardiovasc Surg. 2011;141:311-7.

29. Flood A. JK Rowling says she received 'loads' of rejections before Harry Potter success. The Guardian. March 24, 2015. Available at: https://www.theguardian.com/ books/2015/mar/24/jk-rowling-tells-fans-twitter-loads-rejections-before-harrypotter-success. Accessed June 10, 2017.

30. Maslach C. Burnout: The Cost of Caring. Los Altos, CA: Malor Books, ISHK 2003.

31. Shanafelt TD, Hasan O, Dyrbye LN, Sinsky C, Satele D, Sloan J, et al Changes in burnout and satisfaction with work-life balance in physicians and the general US working population between 2011 and 2014. Mayo Clin Proc. 2015;90:1600-13. 
32. Balch CM, Shanafelt TD, Sloan JA, Satele DV, Freischlag JA. Distress and career satisfaction among 14 surgical specialties, comparing academic and private practice settings. Ann Surg. 2011;254:558-68.

33. Dyrbye LN, Shanafelt TD, Balch CM, Satele D, Sloan J, Freischlag J. Relationship between work-home conflicts and burnout among American surgeons. Arch Surg. 2011;146:211-7.

34. Campbell DA Jr, Sonnad SS, Eckhauser FE, Campbell KK, Greenfield LJ. Burnout among American surgeons. Surgery. 2001;130:696-705.

35. Balch CM, Freischlag JA, Shanafelt TD. Stress and burnout among surgeons: understanding and managing the syndrome and avoiding the adverse consequences. Arch Surg. 2009;144:371-6.

36. Mayo Foundation for Medical Education and Research. Physician well-being program. Available at: http://www.mayo.edu/research/centers-programs/ physician-well-being-program/about. Accessed June 4, 2016.
37. Wood DE. Cardiothoracic surgery: a specialty divided or as one. J Thorac Cardiovasc Surg. 2009;137:1-9.

38. Schachtel HJ. The Real Enjoyment of Living. New York: Dutton; 1954.

39. Pettigrew TF. Samuel Stouffer and relative deprivation. Soc Psychol Q. 2015;78: 7-24.

40. Sheldon KM, Lyubomirsky S. The challenge of staying happier: testing the hedonic adaptation prevention model. Pers Soc Psychol Bull. 2012;38:670-80.

41. Dweck CS. Mindset: The New Psychology of Success. New York: Random House; 2006.

42. Mueller CM, Dweck CS. Praise for intelligence can undermine children's motivation and performance. J Pers Soc Psychol. 1998;75:33-52.

43. Miller JI Jr. The complete cardiothoracic surgeon: qualities of excellence Ann Thorac Surg. 2004;78:2-8.

44. Kron IL. Surgical mentorship. J Thorac Cardiovasc Surg. 2011;142:489-92. 